\title{
A Mosaic of Functional Kainate Receptors in Hippocampal Interneurons
}

\author{
Jeppe K. Christensen, ${ }^{1,2 *}$ Ana V. Paternain, ${ }^{1 *}$ Sanja Selak, ${ }^{1}$ Philip K. Ahring, ${ }^{2}$ and Juan Lerma ${ }^{1}$ \\ ${ }^{1}$ Instituto Cajal, Consejo Superior de Investigaciones Científicas, 28002 Madrid, Spain, and ${ }^{2}$ NeuroSearch, DK-2750 Ballerup, Denmark
}

\begin{abstract}
Although some physiological functions of kainate receptors (KARs) still remain unclear, recent advances have highlighted a role in synaptic physiology. In hippocampal slices, kainate depresses GABA-mediated synaptic inhibition and increases the firing rate of interneurons. However, the sensitivity to agonists of these responses differs, suggesting that the presynaptic and somatic KARs have a distinct molecular composition. Hippocampal interneurons express several distinct KAR subunits that can assemble into heteromeric receptors with a variety of pharmacological properties and that, in principle, could fulfill different roles. To address which receptor types mediate each of the effects of kainate in interneurons, we used new compounds and mice deficient for specific KAR subunits. In a recombinant assay, 5-carboxyl-2,4-di-benzamido-benzoic acid (NS3763) acted exclusively on homomeric glutamate receptor subunit 5 (GluR5), whereas 3S,4aR,6S,8aR-6-((4-carboxyphenyl)methyl) 1,2,3,4,4a,5,6,7,8,8a-decahydroisoquinoline-3-carboxylic acid (LY382884) antagonized homomeric GluR5 and any heteromeric combination containing GluR5 subunits. In hippocampal slices, LY382884, but not NS3763, was able to prevent kainate-induced depression of evoked IPSC. In contrast, neither prevented the concomitant increase in spontaneous IPSC frequency. The selectivity of these compounds was seen additionally in knock-out mice, such that they were inactive in GluR $5^{-1-}$ mice but completely effective in GluR6 ${ }^{-1-}$ mice. Our data indicate that in wild-type mice, CA1 interneurons express heteromeric GluR6-KA2 receptors in their somatic compartments and GluR5-GluR6 or GluR5-KA2 at presynaptic terminals. However, functional compensation appears to take place in the null mutants, a new pharmacological profile emerging more compatible with the activity of homomeric receptors in both compartments: GluR5 in GluR6 ${ }^{-1-}$ mice and GluR6 in GluR5 ${ }^{-1-}$ mice.
\end{abstract}

Key words: excitability; interneuron; kainic acid; glutamate; GluR5; GluR6; KA2; GluR6

\section{Introduction}

Kainate receptor (KAR) subunits form a class of glutamate receptors that are widely distributed in the brain. Although the physiological role of these receptors is still not absolutely clear, recent advances have highlighted the kind of functions that they might play in the brain. Indeed, after the discovery that the 2,3 benzodiazepine GYKI53655 was a specific antagonist of AMPA receptors (Paternain et al., 1995; Wilding and Huettner, 1995), functional studies showed that KARs play a significant role in both synaptic transmission and synaptic plasticity (for review, see Lerma, 2003). The activation of KARs modulates neurotransmitter release from a number of hippocampal synapses, including GABA release at inhibitory terminals that synapse with CA1 pyramidal cells (Clarke et al., 1997; Rodriguez-Moreno et al., 1997; Bureau et al., 1999) (but see Cossart et al., 1998; Frerking et al.,

\footnotetext{
Received June 3, 2004; revised Aug. 24, 2004; accepted Aug. 24, 2004.

This work was supported by Ministerio de Ciencia y Tecnología Grant BFI2003-00161 (J.L.) and European Union Grant QLG3-CT2001-00929. A.V.P. is a postdoctoral fellow of the Autonomous Community of Madrid. We thank Dr. S. F. Heinemann for providing us with the GluR5- and GluR6-deficient mice, Dr.P. H. Seeburg for plasmids, Eli Lilly for a sample of LY303070 and LY382884, and D. Guinea for technical help.

*J.K.C. and A.V.P contributed equally to this work.

Before Nov. 15, 2004, correspondence should be addressed to J. Lerma, Instituto Cajal, Consejo Superior de Investigaciones Científicas (CSIC), Avenida Doctor Arce, 37, 28002 Madrid, Spain, E-mail: lerma@cajal.csic.es; after Nov. 15, 2004, correspondence should be addressed to J. Lerma, Instituto de Neurociencias, CSIC-University Miguel Hernandez, Apdo. 18, San Joan d'Alacant, 03550 Spain, E-mail: lerma@umh.es.

DOI:10.1523/JNEUROSCI.2156-04.2004

Copyright $\odot 2004$ Society for Neuroscience $\quad$ 0270-6474/04/248986-08\$15.00/0
}

1998; Jiang et al., 2001). Indeed, this effect on GABA release is very much in keeping with the presumptive role of these receptors in epilepsy (Ben-Ari, 1985) (for review, see Lerma et al., 2001).

Kainate receptors are assembled from five different subunits, glutamate receptor subunits 5-7 (GluR5-GluR7), KA1, and KA2. Although GluR5-GluR7 can form functional homomeric receptor channels, KA1 and KA2 must form heteromers with these GluR subunits to form receptors with distinct properties (Herb et al., 1992). Although CA1 interneurons mostly express GluR5 and GluR6 subunits (Bureau et al., 1999; Paternain et al., 2000), KA2 may also be present in these cells (Wisden and Seeburg, 1993; Bureau et al., 1999). The activation of these KARs in hippocampal interneurons produces two distinct effects on pyramidal cells: an increase in spontaneous IPSCs, indicative of the depolarization of the somatodendritic compartments in interneurons; and a reduction in the amplitude of evoked IPSC, probably produced by a depression of GABA release. Hence, it seems possible that at least two different populations of receptors exist in CA1 interneurons (Rodriguez-Moreno et al., 2000).

Although some studies have shed light on the functional KAR subunits in hippocampal interneurons (Clarke et al., 1997; Cossart et al., 2001; Mulle et al., 2000), there has been no definitive demonstration of which subunits may be responsible for modulating neuronal excitability. Therefore, we took advantage of the development of subunit selective compounds and the availability 
of mice deficient for KAR subunits to determine the contribution of receptors with different subunit composition to interneuron depolarization and to the modulation of GABA release in the hippocampal CA1 region. Our results show that CA1 interneurons that make synapses with pyramidal neurons express heteromeric GluR6-KA2 in the somatic compartments and GluR5GluR6 or GluR5-KA2 at presynaptic terminals. However, the pharmacological profile of KAR-mediated activity is altered in knock-out (KO) mice. Indeed, it appears that in GluR6 ${ }^{-1-}$ mice, homomeric GluR5 receptors form both in the soma and at terminals, whereas in GluR5 ${ }^{-/-}$mice, homomeric GluR6 receptors are found. These results indicate a functional compensation in the interneurons of $\mathrm{KO}$ mice, such that we must exercise caution when interpreting results from mice in which KAR subunits have been deleted.

\section{Materials and Methods}

Transient cDNA transfection. Plasmids encoding the GluR6 (VCR or VCQ versions), GluR5-2a (Q or R form), and KA2 were a gift from Dr. P. H. Seeburg (Max-Planck Institute, Heidelberg, Germany). The plasmids were cotransfected with an enhanced green fluorescent protein expression vector into human embryonic kidney 293 (HEK293) cells by electroporation (gene pulser; Bio-Rad, Hercules, CA) or using Lipofectamine PLUS (Invitrogen, Carlsbad, CA). The GluR5 and KA2 plasmids were cotransfected in 1:1 or 1:3 ratios, whereas a ratio of 1:2.5 was used for GluR6 and GluR5 and 1:10 when GluR6 was cotransfected with $K A 2$. These ratios were sufficient for GluR6 to generate a large proportion of heteromeric receptors with GluR5 and KA2 subunits (Paternain et al., 2000, 2003). Indeed, this fact was systematically evaluated by applying AMPA and ( $R S$ )-2- $\alpha$-amino-3-(3-hydroxy-5-tert-butylisoxazol4-yl) propanoic acid (ATPA), which activates heteromeric GluR6GluR5 or GluR6-KA2 but not homomeric GluR6. Afterward, the cells were seeded in Petri dishes in DMEM supplemented with 10\% fetal calf serum and antibiotics, and then maintained in a humidified incubator at $37^{\circ} \mathrm{C}$ and $5 \% \mathrm{CO}_{2}$. Highly fluorescent cells were identified and selected for recording. In our hands, GluR5 (up to $10 \mu \mathrm{g}$ ) did not yield any current when transfected alone (Paternain et al., 2000, 2003). Therefore, we used HEK293 cells stably expressing human GluR5-1a(Q) to evaluate homomeric GluR5 receptors as described previously (Varming et al., 2001).

Preparation of mouse hippocampal homogenates. Hippocampi were isolated from 2-week-old female GluR5 ${ }^{-1-}$, GluR6 ${ }^{-1-}$, and wild-type (WT) C57 mice. Hippocampi were hand-homogenized with a Tefloncoated homogenizer in buffer containing $20 \mathrm{~mm} 3-(\mathrm{N}$ morpholino)propanesulfonic acid, $\mathrm{pH} 7.0,150 \mathrm{~mm} \mathrm{KCl,} 1 \%$ Triton $\mathrm{X}-100$, and protease inhibitor mixture. The homogenized tissue was incubated on the rotator for $45 \mathrm{~min}$ at $4^{\circ} \mathrm{C}$ to facilitate solubilization of the proteins. After the solubilization, large membrane fractions were removed by centrifugation at $500 \times g$, and protein concentration was determined referring to a Bradford colorimetric protein assay with bovine serum albumin as a standard (Bio-Rad). Fifteen micrograms of proteins from each homogenate were separated by SDS-PAGE, transferred to nitrocellulose, and used for immunoblotting using established protocols (Selak et al. 1999). The following antibodies were used: goat anti-KA2 (N-17; 1:100; Santa Cruz Biotechnology, Santa Cruz, CA), rabbit anti-KA2 (C-terminal; 1:3000; Upstate Biotechnology, Charlottesville, VA), and mouse monoclonal antibodies to $\beta$-actin (1:3000; Sigma, St. Louis, MO). The intensity of the antibody signal was assessed by densitometric analysis.

Electrophysiological recordings and perfusion procedures. Electrophysiology experiments were performed $1 \mathrm{~d}$ after plasmid transfection in HEK293 cells. Membrane currents were recorded at a given membrane potential using the whole-cell configuration of the patch-clamp technique and using a List Electronics (Darmstadt, Germany) EPC-7 amplifier or a HEKA Elektronik (Lambrecht/Pfalz, Germany) EPC-9 amplifier. Series resistance was compensated by $50-80 \%$, and the patch electrodes were fabricated from borosilicate glass with a resistance of 5-10 $\mathrm{M} \Omega$.
Currents were filtered at $1 \mathrm{kHz}$ (two-pole Butterworth filter, $-12 \mathrm{~dB}$ / octave) and transferred at a sampling rate of $1-5 \mathrm{kHz}$ into a personal computer for analysis and display purposes using pCLAMP software (Axon Instruments, Foster City, CA) or PULSE software (HEKA Elektronik). All of the experiments were performed at room temperature $\left(22-25^{\circ} \mathrm{C}\right)$. The cells were rapidly perfused using double-barreled application pipettes made from theta glass tubes $(1.5 \mathrm{~mm}$ outer diameter; World Precision Instruments, Sarasota, FL). The application pipettes were mounted on a piezoelectric device connected to a piezo driver (PZ150M; EXFO, Vanier, Quebec, Canada) driven by transistor-transistor logic pulses. Alternatively, we used a linear array of eight glass tubes placed $200-300 \mu \mathrm{m}$ from the cell body and driven by a motorized device under the control of a personal computer (Lerma et al., 1998). Ringer's solution with and without drugs flowed from adjacent barrels, and solution changes were achieved by lateral displacement of the whole perfusion array.

Hippocampal slices were prepared from 14- to 16-d-old mice, as described in detail previously (Rodriguez-Moreno et al., 1997). The procedures for handling and killing animals used in this study followed the European Commission guidelines (86/609/CEE) for handling experimental animals and were supervised by the veterinarian at the Cajal Institute. Briefly, a hemibrain containing the hippocampus was cut into $300-\mu \mathrm{m}$-thick sagittal slices with a vibratome slicer (Leica VT1000 S; Leica Microsistemas, Barcelona, Spain), and the slices were maintained continuously oxygenated for at least $1 \mathrm{hr}$ before use. Electrophysiological recordings were performed from neurons visually identified by infrareddifferential interference contrast microscopy using a $40 \times$ water immersion objective. All of the experiments were performed at room temperature $\left(22-25^{\circ} \mathrm{C}\right)$. The slices were continuously perfused with a solution of the following (in mM): $124 \mathrm{NaCl}, 2.69 \mathrm{KCl}, 1.25 \mathrm{KH}_{2} \mathrm{PO}_{4}, 4 \mathrm{MgCl}_{2}, 2$ $\mathrm{CaCl}_{2}, 26 \mathrm{NaHCO}_{3}$, and 10 glucose, pH 7.3 (300 mOsm), supplemented with $25 \mu \mathrm{M}$ LY303070 (i.e., the active isomer of GYKI53655) and APV (50 $\mu \mathrm{M})$. Drugs were applied by gravity, switching between perfusion lines. IPSCs were evoked by electrical pulses applied to the stratum oriens by a bipolar electrode. Tight-seal ( $>1 \mathrm{G} \Omega$ ) whole-cell recordings were obtained from the cell body of pyramidal neurons. Patch electrodes were made from borosilicate glass and had a resistance of 3-6 M $\Omega$ when filled with the following (in mM): $122 \mathrm{CsCl}, 8 \mathrm{NaCl}, 10$ HEPES, 5 EGTA, and 10 TEA, pH 7.3 (287 mOsm), supplemented with $5 \mathrm{~mm}$ lidocaine $N$-ethyl bromide (QX314; Alomone Laboratories, Jerusalem, Israel). Under these conditions, the high concentrations of chloride in the pipette caused the IPSC to appear as an inward current. Neurons were voltage-clamped using an Axopatch 200A amplifier (Axon Instruments). Access resistance (8-30 M $\Omega$ ) was regularly monitored during recordings, and cells were rejected if it changed $>15 \%$ during the experiment. Data were filtered at $2 \mathrm{kHz}$, digitalized, and stored on a computer using the LTP114J software developed by Bill Anderson (Anderson and Collingridge, 2001) (http:// www.ltp-program.com). Statistical differences were evaluated by the two-tailed unpaired Student's $t$ test.

Kainate was obtained from either Ocean Produce International (Dartmouth, Nova Scotia, Canada) or Tocris Cookson (Bristol, UK). Disodium glutamate and other salts were obtained from either Sigma or Merck (Darmstadt, Germany). ATPA and 5-carboxyl-2,4di-benzamido-benzoic acid (NS3763) were a gift from Dr. J. Drejer (NeuroSearch, Ballerup, Denmark); LY303070 was provided by Eli Lilly (Indianapolis, IN) or custom-synthesized by ABX Logistics (Radeberg, Germany). 3S,4aR,6S,8aR-6-((4-Carboxyphenyl)methyl) $1,2,3,4,4 \mathrm{a}, 5,6,7,8,8 \mathrm{a}$-decahydroisoquinoline-3-carboxylic acid (LY382884) was a generous gift from Eli Lilly.

\section{Results}

Two compounds have been described recently: LY382884 and NS3763, which appear to show certain specificity for KARs with different subunit compositions (Bortolotto et al., 1999; Smolders et al., 2002; Alt et al. 2004; Christensen et al., 2004). To confirm that this was the case, we characterized these compounds in HEK293 cells expressing different combinations of KAR subunits. Both NS3763 and LY382884 effectively antagonized 


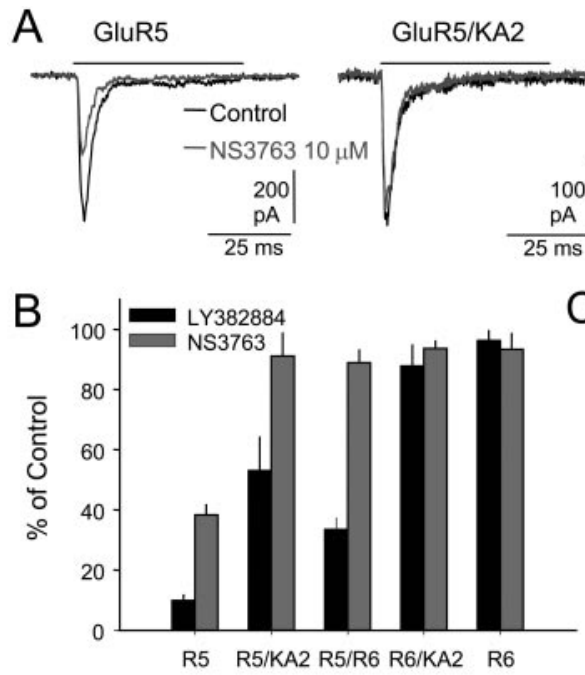

\section{GluR5/GluR6}

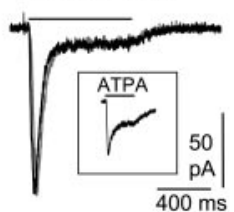

$\mathrm{C}_{\text {GluR6 }}$
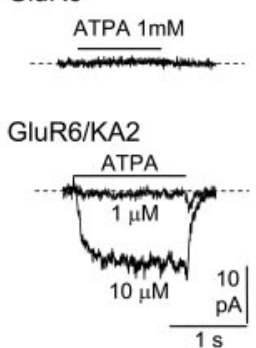

Figure 1. Sensitivity of homomeric and heteromeric kainate receptors to the NS3763 and LY382884 antagonists. A, Examples of current responses in HEK293 cells transiently transfected with GluR5 and either KA2 or GluR6 and in cells stably transfected with GluR5 alone. Inset, Response induced by ATPA (100 $\mu \mathrm{M})$, revealing the presence of heteromeric GluR5-GluR6 receptors in the membrane. The rapid application of $1 \mathrm{~mm}$ glutamate in the presence (gray trace) and absence (black trace) of the antagonist is denoted by horizontal bars. B, Summary of the effect of $10 \mu \mathrm{m}$ NS3763 or LY383884 on kainate receptors of different subunit composition. The amplitudes of the responses in the presence of the antagonist are expressed as a percentage of the responses obtained by the application of $1 \mathrm{~mm}$ glutamate in its absence. The values are the mean \pm SEM of 4-12 separate experiments. C, Heteromeric GluR6-KA2 but not homomeric GluR6 receptors are sensitive to micromolar concentrations of the agonist ATPA.

glutamate-induced responses in cells stably expressing homomeric GluR5 receptors, although LY382884 was the more potent antagonist of the two (Fig. 1). However, NS3763 specifically inhibited homomeric GluR5 because it was completely ineffective at $10 \mu \mathrm{M}$ on heteromeric GluR5 receptors that incorporated either GluR6 or KA2 (Fig. 1A). In contrast, LY382884 still prevented the activation of heteromeric GluR5 receptors. Neither compound acted on receptors that did not contain GluR5 (i.e., GluR6 and GluR6-KA2) (Fig. 1B).

We did not detect responses after transient transfection of GluR5 in HEK293 cells. However, when the same plasmid was cotransfected with either GluR6 or KA2, functional receptors were formed. Therefore, any response to kainate in cells transfected with GluR5 and KA2 subunits must be via heteromeric receptors because KA2 subunits do not form homomeric channels. Thus, the contribution of homomeric GluR5 complexes to the action of drugs under study could be discarded. However, functional GluR6 homomers could still coexist with GluR5GluR6 or GluR6-KA2 receptors in cells cotransfected with GluR6 and either GluR5 or KA2. We estimated the relative abundance of GluR6-KA2 heteromers as described previously (i.e., looking at the ratio of responses to AMPA and glutamate) (Paternain et al., 2003) and by the sensitivity of these cells to ATPA (Fig. 1C). LY382884 and NS3763 were inactive on these responses regardless of the ratio found. The formation of GluR5-GluR6 heteromeric complexes was analyzed by observing the ATPAinduced responses (Fig. 1A). In these experiments, the fraction of glutamate-induced current desensitized by a high concentration of ATPA could be used to estimate the fraction of heteromeric GluR5-GluR6 receptors (Paternain et al., 2000) because this agonist is inactive on homomeric GluR6 but desensitizes heteromeric GluR5 and GluR6. Heteromeric complexes were estimated

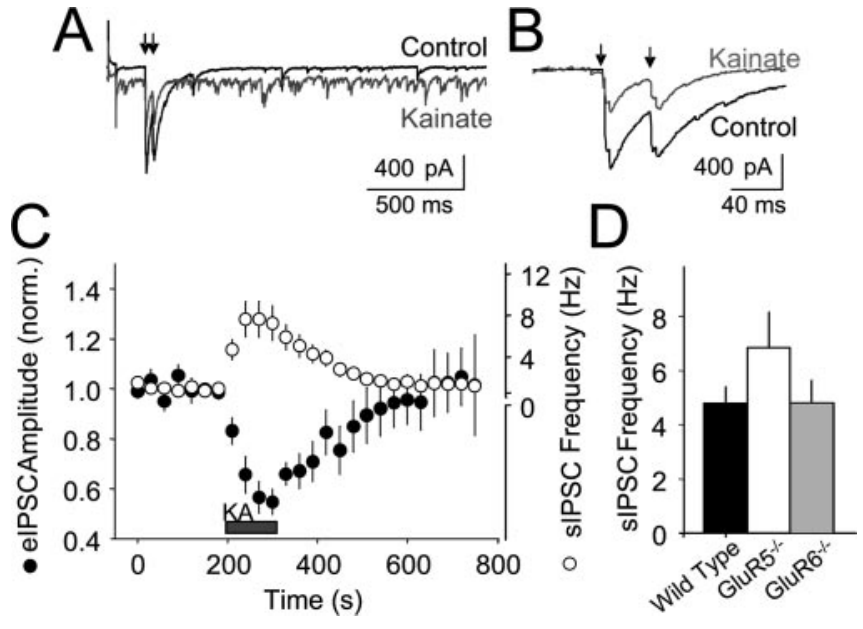

Figure 2. Effect of kainate receptor activation on spontaneous and evoked IPSCs recorded from CA1 pyramidal cells. A, IPSCs were evoked by paired pulses applied to the stratum oriens (arrows; 40 msec interval), in the presence of antagonists of NMDA (APV; $50 \mu \mathrm{M}$ ) and AMPA (LY303070;25 $\mu \mathrm{M}$ ) receptors. Black and gray traces correspond to readings before and during kainate $(3 \mu \mathrm{M})$ perfusion, respectively. $B$, The evoked IPSCS are superimposed after subtracting the holding current. C, Time course of evoked IPSC amplitudes (filled circles) and frequency (unfilled circles), before, during, and after kainate application. Points are the mean \pm SEM of 14 experiments. D, Mean basal frequency of spontaneous IPSC in wild-type and GluR5 or GluR6 KO mice. The spontaneous IPSC frequency was computed for a 3 min segment in each cell from $6-14$ separate experiments. The columns represent the mean \pm SEM.

to be responsible for $>80 \%$ of the current in these experiments, and although NS3763 did not act on these channels, the degree of inhibition induced by LY382884 was corrected accordingly.

Therefore, we concluded that although LY382884 antagonizes native receptors containing GluR5 subunits (Alt et al., 2004), NS3763 would only act on homomeric GluR5 receptors (Christensen et al., 2004).

\section{The double action of kainate on CA1 interneurons}

We indicated previously that at least two populations of KARs exist in CA1 interneurons: one presumably located in the somatodendritic compartment and the other at synaptic terminals (Rodriguez-Moreno et al., 2000). In the presence of the selective AMPA receptor antagonist LY303070 $(25 \mu \mathrm{M})$ and the NMDA receptor antagonist APV $(50 \mu \mathrm{M})$, activation of interneuronal somatodendritic KARs can be detected through the frequency of spontaneous IPSCs (sIPSCs) in CA1 pyramidal cells (Cossart et al., 1998; Frerking et al., 1998; Rodriguez-Moreno et al., 2000). The activation of presynaptic KARs can be evaluated by the degree of depression of evoked IPSCs (eIPSCs). Indeed, a 2 min perfusion of kainate $(3 \mu \mathrm{M})$ provoked an increase in the frequency of sIPSCs (Fig. 2A,C) and a reduction of the peak amplitude of eIPSCs (Fig. 2B,C). Similarly, there was an increase in the holding current $(122 \pm 12 \mathrm{pA} ; n=5)$ (Fig. $1 A)$, which was mostly a result of the postsynaptic summation of sIPSCs because it was mostly prevented, although not eliminated ( $16 \pm 3$ pA remained; $n=5$ ), by TTX. The effect of kainate was reversible, and sIPSC frequency, eIPSC amplitude, and the holding current returned to near control levels after the removal of the agonist. All of these parameters were also evaluated in hippocampal slices prepared from mice deficient for either GluR5 (Mulle et al., 2000) or GluR6 (Mulle et al., 1998). Interestingly, the basal spontaneous activity (i.e., sIPSC frequency) was essentially identical in the $\mathrm{KO}(6.8 \pm$ $1.3 \mathrm{~Hz} ; n=7$; and $4.8 \pm 0.8 \mathrm{~Hz} ; n=6$, in GluR5 ${ }^{-1-}$ and 


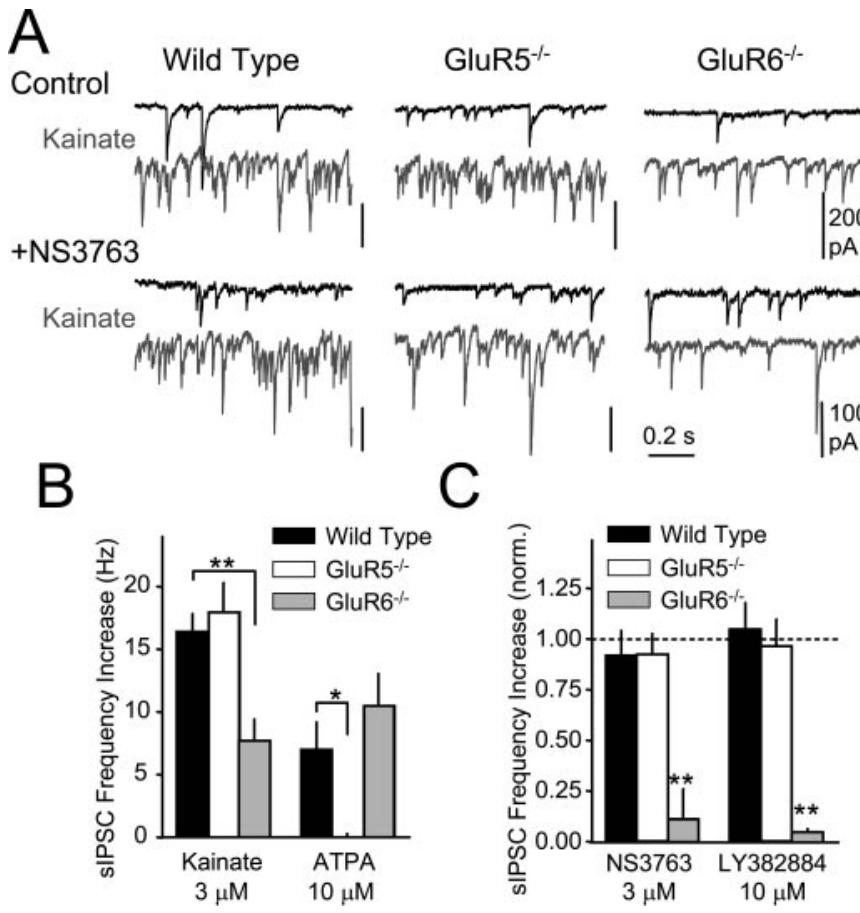

Figure 3. Effect of antagonists on the increase in the kainate-induced frequency of spontaneous IPSCs in wild-type and $\mathrm{KO}$ mice. $A$, Representative recordings before (black traces) and during (gray traces) kainate $(3 \mu \mathrm{M}$ ) application in the presence and absence of NS3763 $(3 \mu \mathrm{M})$. Traces correspond to different neurons because kainate was applied just once per slice. $B$, Increase in spontaneous IPSC frequency induced by kainate and ATPA in wild-type and kainate receptor $\mathrm{KO}$ mice. Bars are the averages of data obtained from 5-14 experiments. C, Effect of NS3763 and LY382448 on the kainate-induced increase in spontaneous IPSC frequency. The dotted line represents the effect of kainate $(3 \mu \mathrm{M})$ in the absence of antagonist. ${ }^{*} p<0.05$; ${ }^{* *} p<0.005$, two-tailed Student's unpaired $t$ test.

GluR6 $^{-1-}$ mice, respectively) and wild-type $(4.8 \pm 0.6 \mathrm{~Hz} ; n=$ 14) mice (Fig. 2D).

\section{Characteristics of kainate receptors mediating the increase of sIPSC frequency}

Exposure to kainate $(3 \mu \mathrm{M})$ increased the frequency of sIPSCs to a similar extent in both WT and GluR5 ${ }^{-1-}$ neurons $(16 \pm 1 \mathrm{~Hz}$; $n=14$; and $18 \pm 1.3 \mathrm{~Hz} ; n=7$, respectively) (Fig. $3 A, B$ ). However, kainate was less efficient in inducing this increase in SIPSC frequency in neurons from GluR6 ${ }^{-1-}$ mice $(8.0 \pm 2 \mathrm{~Hz} ; n=6$; $p<0.005$ ) (Fig. $3 A, B$ ). We also analyzed the effects of applying ATPA, an agonist that activates receptors containing GluR5. In WT slices, the active isomer S-ATPA $(10 \mu \mathrm{M})$ moderately increased sIPSC frequency $(7 \pm 2 \mathrm{~Hz} ; n=9$ ) (Fig. $3 B$ ), which in principle could indicate the existence of receptors containing GluR5 subunits in the somatodendritic compartment. A similar effect was produced by S-ATPA in slices from GluR6 ${ }^{-1-}$ animals $(11 \pm 3 \mathrm{~Hz} ; n=8)$ but not in slices prepared from GluR5deficient mice. We then studied the effect of the antagonists NS3763 and LY382884 on the responses mediated by receptors situated in the somatodendritic compartment. In WT animals, LY382884 and NS3763 were unable to antagonize the kainateinduced increase in sIPSC frequency, a characteristic also observed in GluR5 KO mice (Fig. 3C). However, both antagonists severely reduced the increase in sIPSC frequency in mice in which the GluR6 subunits were deleted. In the presence of NS3763, the kainate-induced increase in sIPSC frequency was prevented by $89 \pm 14 \%(n=6)$, whereas LY382884 almost completely abolished this response by $95 \pm 2 \%(n=5)$ (Fig. $3 C)$.
A

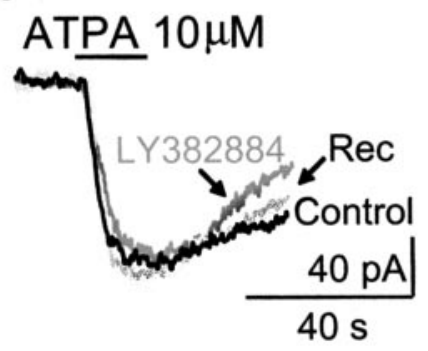

$\mathrm{B}$

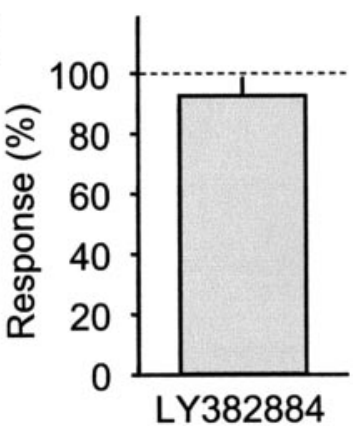

Figure 4. Effect of LY38288 on ATPA-induced currents in hippocampal interneurons. A, Inward currents induced by bath-applied ATPA (10 $\mu \mathrm{M})$ in hippocampal interneurons before (black trace), during (dark gray trace), and after (light gray trace) application of LY382884 (10 $\mu \mathrm{M})$. LY382884 was introduced in the chamber at least $4 \mathrm{~min}$ before the agonist. Rec, Recovery. $B$, Summary of the ATPA-induced responses in the presence of LY382884. The values are the mean \pm SEM expressed as a percentage of control responses (4 slices).

The failure of LY382884 to inhibit the kainate-induced increase of sIPSC frequency in WT mice, coupled to the antagonism of all of the recombinant receptors containing GluR5 subunits, rules out the possible existence of receptors containing GluR5 in the somatodendritic compartment of WT CA1 interneurons. However, it has been shown that $10 \mu \mathrm{M}$ ATPA is active on heteromeric receptors made up of GluR6 and KA2 (Fig. 1C) (Paternain et al., 2000; Alt et al. 2004). To further assess the presence of heteromeric GluR6-KA2 at the somatodendritic compartment and that the action of ATPA on the frequency of sIPCS was mainly attributable to activation of this and no other combination of subunits, we studied whether LY389884 was able to antagonize the depolarizing action of ATPA. Thus, we measured the change in holding current induced by bath application of ATPA $(10 \mu \mathrm{M})$ in interneurons in the presence of TTX to avoid spontaneous firing. Cells laying in the stratum oriens or radiatum with an ovoid shape were recorded as interneurons. At a holding potential of $-60 \mathrm{mV}$, application of ATPA increased the holding current in 9 of 11 cells studied by $121.4 \pm 23 \mathrm{pA}(n=9)$. Such a change in holding current was not antagonized by the LY382884 $(10 \mu \mathrm{M})(92.4 \pm 6 \%$ of the current remained) (Fig. 4$)$, ruling out the possibility that somatodendritic GluR5-containing receptors are implicated in the action of ATPA. Therefore, the inability to activate receptors by ATPA in the absence of GluR5 indicates that the receptors mediating kainate-induced depolarization of interneuron membrane do not contain the KA2 subunit.

These data indicate that functional GluR5-containing KARs are present in the somatodendritic compartment of CA1 interneurons in GluR6-deficient but not in WT mice. In contrast, receptors containing GluR6 subunits appear to be present in this compartment in both WT and GluR5-deficient mice. However, their sensitivity to ATPA indicates that they must include the KA2 subunit in WT but surprisingly not in GluR $5^{-1-}$ mice. Consistent with this assumption, ATPA $(10 \mu \mathrm{M})$ induced no current in interneuron from the GluR5-deficient mice (data not shown).

Properties of kainate receptors mediating inhibition of GABA release on CA1 pyramidal neurons

Several studies have shown that the activation of presynaptic KARs can depress GABAergic synaptic transmission in the rat hippocampus (Clarke et al., 1997; Rodriguez-Moreno et al., 1997, 2000; Rodriguez-Moreno and Lerma, 1998; Cunha et al., 2000). This kainate-induced decrease in the amplitude of the eIPSCs has been reported in wild-type mice as well as in mice lacking either 
the GluR5 or GluR6 subunits (Bureau et al., 1999; Mulle et al., 2000). We further studied the pharmacology of this KARmediated activity in WT as well as in GluR5- and GluR6-deficient mice. Application of $3 \mu \mathrm{M}$ kainate caused a decrease of $42 \pm 4 \%$ $(n=14)$ in the amplitude of the eIPSCs in slices prepared from WT mice (Fig. 5A,B). In accordance with a previous report (Mulle et al., 2000), kainate also had a similar effect on eIPSC amplitude in GluR5 ${ }^{-1-}$ (inhibition of $35 \pm 8 \% ; n=8$ ) and GluR6 $^{-1-}(35 \pm 10 \%$ depression; $n=6)$ mice (Fig. $\left.5 A, B\right)$. The inhibitory action of kainate was not significantly affected by the presence of NS3763 in WT mice ( $26 \pm 20 \%$ reduction; $n=14$; $p>0.05$ ) (Fig. 5C). However, in the presence of LY382884, the kainate-induced depression of eIPSCs was reduced by $66 \pm 21 \%$ $(n=8 ; p<0.05)$ (Fig. $5 C)$. As expected, NS3763 or LY382884 had no effect on the kainate-induced depression of eIPSC amplitude in GluR5 ${ }^{-1-}$ mice but completely abolished the activity of kainate in GluR6 ${ }^{-1-}$ mice. Indeed, NS3763 and LY382884 prevented the kainate-induced depression of eIPSC amplitude by $95 \pm 9 \%(n=6)$ and $85 \pm 25 \%(n=4)$, respectively, in the absence of GluR6 (Fig. 5C).

These results indicate that GluR5-containing receptors are present in the synaptic terminals of CA1 interneurons in WT and GluR6 $^{-1-}$ mice. Because NS3763 exclusively inhibits homomeric GluR5 receptors in recombinant systems, these must be the receptors assembled in GluR6-deficient terminals. Exposure to ATPA $(10 \mu \mathrm{M})$ caused a modest but significant reduction of eIPSC amplitude in WT mice (13 $\pm 4 \%$ inhibition; $n=9 ; p<$ $0.05)$. Although such an effect was not observed in GluR5deficient mice, it was twofold larger in neurons from GluR6 ${ }^{-1-}$ mice $(27 \pm 6 \% ; n=8)$, which is consistent with the aforementioned results.

\section{KA2 subunit is downregulated in GluR5- and GluR6- deficient mice}

The data obtained in $\mathrm{KO}$ mice indicated a change in the pharmacological profile of kainate receptors expressed at both somatodendritic and presynaptic compartments, more compatible with the existence of receptors lacking the KA2 subunit. Therefore, we decided to study whether this subunit was actually downregulated in mice deficient for either GluR5 or GluR6. Figure 6 shows the results obtained by Western blot analysis from homogenates obtained from hippocampi isolated from wild-type and $\mathrm{KO}$ mice. KA2 protein was detected by both $\mathrm{N}$ - and C-terminal-specific antibodies. As can be seen, in both cases, KA2 protein is significantly reduced in GluR5 ${ }^{-1-}$ mice and almost absent in GluR6 ${ }^{-1-}$ mice. These results extend and support conclusions achieved from pharmacological data, in that KA2 subunit protein is primarily downregulated when one of the main subunits, GluR5 or GluR6, are absent, therefore decreasing the chance to form heteromeric kainate receptors.

\section{Discussion}

In this study, we show that the subunit composition of native KARs expressed in the somatodendritic compartment differs from that in the presynaptic compartment of CA1 hippocampal interneurons. Although the somatodendritic receptors are GluR6-KA2 heteromers, presynaptic receptors contain GluR5 and either GluR6 or KA2. Moreover, experiments performed in mice deficient for either GluR5 or GluR6 demonstrated that in the absence of one of these subunits, the formation of heteromeric receptors was not favored. This is most likely attributable
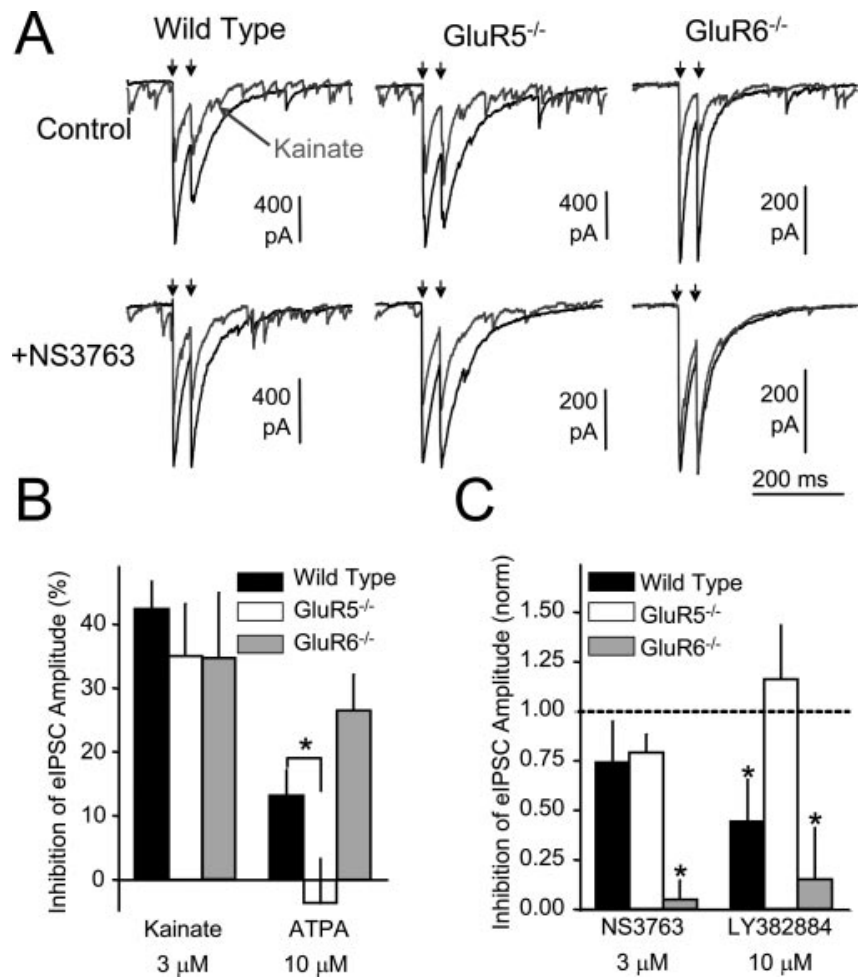

Figure 5. Effect of kainate receptor antagonists on the kainate-induced reduction of evoked IPSC amplitude in wild type and K0 mice. $A$, Representative evoked IPSCS before (black records) and during (gray traces) application of kainate ( $3 \mu \mathrm{m}$ ) in the presence and absence of NS3763 (3 $\mu \mathrm{m})$. Recordings are from different neurons because kainate was applied just once per slice. $B$, Inhibitory effects of kainate and S-ATPA on the amplitude of evoked IPSCs in wild-type and KO animals. C, Effect of kainate receptor antagonists on the kainate-induced inhibition of evoked IPSCs. The dotted line represents the inhibitory effect induced by kainate in the absence of antagonists. Bars correspond to the mean \pm SEM of 3-14 experiments. ${ }^{*} p<0.05$, two-tailed Student's unpaired $t$ test.

to a drastic reduction of KA2 subunit levels, as shown by Western blotting.

Our conclusions are based on the assumption that $3 \mu \mathrm{M}$ kainate is sufficient to activate all of the types of KAR complexes and that $10 \mu \mathrm{M}$ ATPA activates both GluR6-KA2 heteromeric receptors and complexes containing GluR5. This has been illustrated previously (Paternain et al., 2000; Alt et al., 2004) and was confirmed in experiments here (Fig. $1 C$ ). We also analyzed the activity of the newly developed KAR antagonists, namely NS3763 and LY382884. The inhibitory effects of these antagonists on homomeric and heteromeric KAR complexes expressed in HEK293 cells were confirmed (Fig. 1). In agreement with previous studies, NS3763 $(10 \mu \mathrm{M})$ antagonized homomeric GluR5 receptors (Christensen et al., 2004). Furthermore, we found that this compound acts exclusively on homomeric GluR5 and not on heteromeric receptors. In contrast, LY382884 $(10 \mu \mathrm{M})$ was active on any GluR5-containing complex (i.e., GluR5, GluR5-KA2, and GluR5-GluR6) (Alt et al., 2004). However, when studying the action of a drug on heteromeric receptors, some caution must be exercised because mixed populations of homomeric and heteromeric receptors may coexist in the membrane. In our present and previous experiments, transient transfection of GluR5 alone did not generate measurable currents (Paternain et al., 2000, 2003; Alt et al., 2004), and it is well known that KA2 subunits do not form functional homomeric receptors (Herb et al., 1992). For this reason, we excluded any contribution of homomeric GluR5 


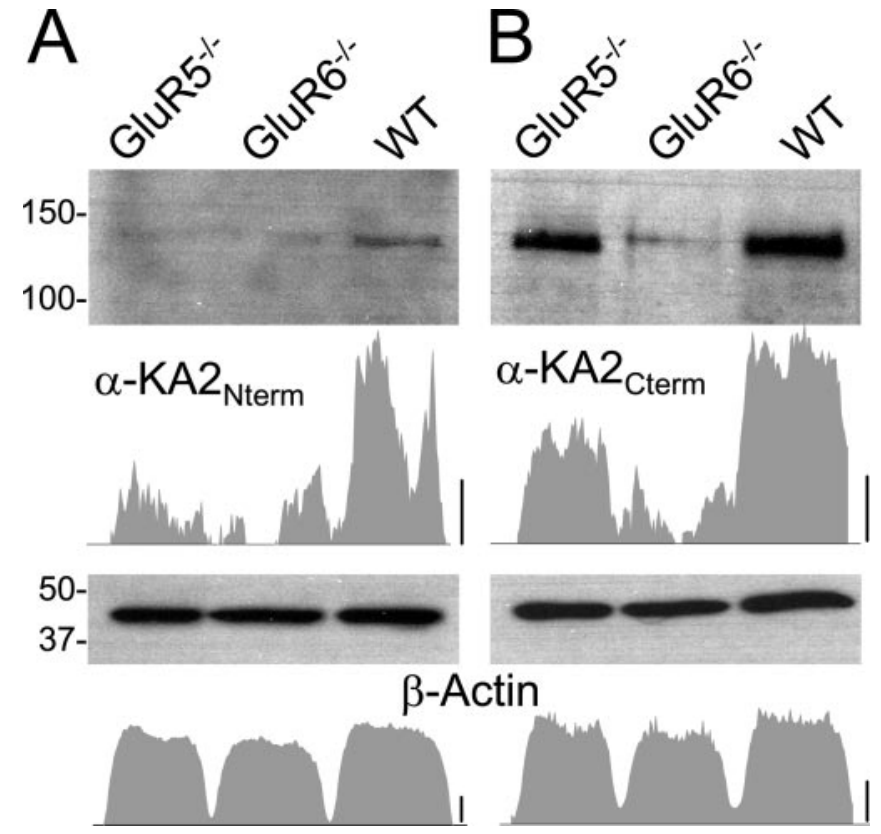

Figure 6. The KA2 subunit is downregulated in GluR5- and GluR6-deficient mice. Western blot analysis of hippocampal homogenates showed that the protein levels of the KA2 subunit were much lower in both GluR5- and GluR6-deficient mice compared with WT mice. The signals obtained by antibodies directed toward N-terminal $\left(\alpha-\mathrm{KA2}_{\mathrm{Nterm}}\right)(A)$ or C-terminal $(\alpha-$ $\mathrm{KA}_{\text {(term }}$ ) (B) epitopes of KA2 were assessed by densitometric analysis. Densitometry profiles of immunoblots are shown for each case. $\beta$-Actin was used as a loading control in each case. Calibration: KA2 blots, 0.02 arbitrary units; $\beta$-actin blots, 0.2 arbitrary units.

complexes to glutamate-induced responses in these experiments. Because the coexistence of functional GluR6 homomers with GluR5-GluR6 or GluR6-KA2 receptors was possible in cells cotransfected with GluR5 and GluR6 or GluR6 and KA2, respectively, we estimated the relative abundance of GluR6-KA2 and GluR5-GluR6 heteromers as described previously (Paternain et al., 2003). LY382884 and NS3763 were inactive when GluR6 and KA2 were expressed, whereas the inhibitory action of LY382884 was larger because the estimated fraction of GluR5-GluR6 heteromeric receptors was higher.

The conclusions regarding the composition of KARs in interneuronal compartments are essentially illustrated in Figure 7. In WT animals, the pharmacological profile after the activation of somatodendritic KARs is similar to that found in heterologous systems in which GluR6 and KA2 subunits are coexpressed. Although more abundant in pyramidal cells, KA2 subunits are also expressed by some interneurons in the hippocampus (Bureau et al., 1999). This is reminiscent of GluR6, which is highly abundant in principal cells, yet it is also expressed in interneurons (Bureau et al., 1999; Paternain et al., 2000). Consequently, the formation of heteromeric GluR6-KA2 subunits seems probable, at least in one population of interneurons. It therefore seems possible that in situ hybridization might underestimate the expression of these two subunits in interneurons because receptors made up of both subunits mediate depolarization of the somatodendritic membrane. In contrast, the modulation of GABA release (estimated by the amplitude of eIPSCs) detected in WT animals is consistent with the presence of heteromeric GluR5 receptors. However, it was not possible for us to differentiate between GluR5 receptors associated with KA2 or GluR6 subunits because both heteromers presented similar agonist and antagonist properties. Indeed, the possibility remains that both types of receptors coexist in termi-

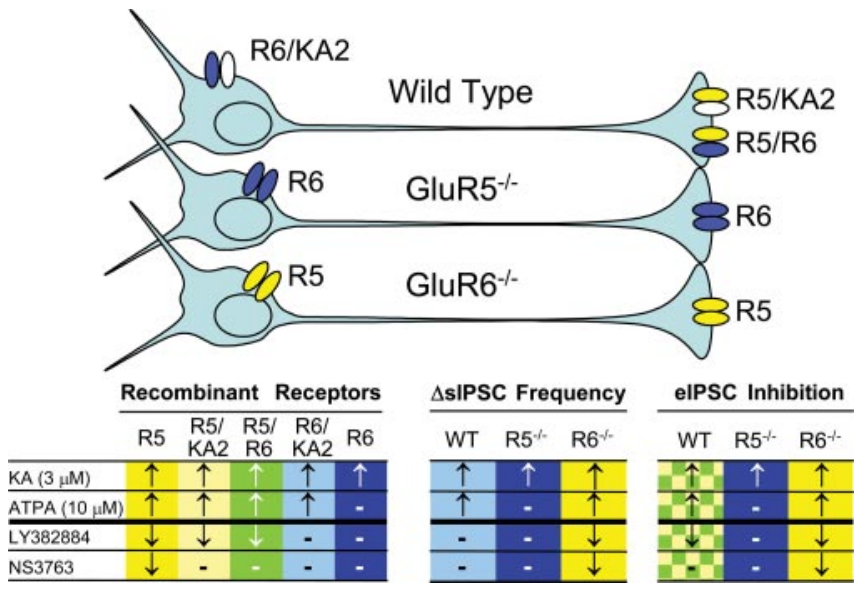

Figure 7. Diagram summarizing the deducted subunit composition of somatic and presynaptic kainate receptors in $\mathrm{CA} 1$ interneurons from wild-type and $\mathrm{KO}$ mice. The table at the bottom summarizes the main activity of agonists and antagonists on the two parameters studied. $\uparrow$ indicates that the agonist stimulates the receptor, whereas $\downarrow$ indicates that the antagonist significantly reduced receptor activation; - indicates that the compound was inactive in antagonizing or stimulating receptors. Each color represents a particular pharmacological profile. Note that although inhibition of evoked IPSCs (i.e., presynaptic activity) presents a profile compatible with both heteromeric GluR5-GluR6 (green) and GluR5-KA2 (cream) receptors, the behavior of the IPSC frequency (i.e., somatodendritic receptor activity) only fits with the heteromeric GluR6 -KA2 profile (light blue). The situation is drastically altered in K0 mice, in which the corresponding pharmacological profiles exclusively match profiles of homomeric receptors (yellow or blue).

nals. It should be noted that native KARs may not be identical to the recombinant heteromeric combinations that we studied. The existence of native receptors made up of different isoforms of the subunits that we used but still with similar pharmacological properties could not be excluded. However, based on present and previous data, we think that Figure 7 represents the most parsimonious conclusion in terms of subunit composition of native KARs, regardless of the specific isoform involved.

Although there are some differences in magnitude, the data we present are comparable with those observed previously in mice by Bureau et al. (1999) and Mulle et al. (2000). It was clear from our results, however, that somatodendritic receptors do not correspond to heteromeric GluR5-GluR6 receptors. This is in contrast to the conclusion reached by Mulle et al. (2000), deduced from the observation that kainate responses were only abolished in the dual GluR5-GluR6 KO mice. Indeed, the capacity of $3 \mu \mathrm{M}$ kainate to stimulate sIPSCs in WT and GluR5 knock-out mice was reduced albeit not eliminated in GluR6 ${ }^{-1-}$ mice (Fig. 3). Although a reduction in number and/or conductance of somatodendritic receptors is possible (Swanson et al., 1996), this is consistent with the observation that the potency of kainate on homomeric GluR5 receptors is much lower than on GluR6-KA2 (Alt et al., 2004). The change of pharmacological profile of these responses indicates that GluR5 can replace the GluR6 subunit in the somatodendritic compartment but does not contradict the need for GluR6 to induce this effect in WT animals. Something similar happens at the presynaptic terminals: in the absence of GluR5, GluR6 becomes involved in modulating GABA release. Therefore, the selective pharmacological profiles in these compartments led us to conclude that such compensatory mechanisms are at play in these $\mathrm{KO}$ mice. In GluR6-deficient mice, both the increase in sIPSC frequency and the depression of eIPSCs not only become sensitive to LY382884, as expected, but both were also effectively antagonized by NS3763, a drug that exclusively 
acts on homomeric GluR5 receptors. In contrast, and as expected in GluR5-deficient mice, LY382884 and NS3763 were unable to antagonize the kainate-induced increase of sIPSC frequency or depression of eIPSC amplitude, but these effects were not induced by ATPA. This lack of sensitivity to ATPA indicates that GluR6-KA2 heteromeric receptors are not present in the interneurons of GluR5 ${ }^{-1-}$ mice. Therefore, the results imply that compensatory mechanisms exist in which one KAR subunit may substitute for the other in hippocampal interneurons. Although there are many examples of functional compensation after gene inactivation, what it is remarkable in the present case is that the absence of one of these subunits precludes the formation of heteromeric receptors by the others. Western blot analysis indicated that the KA2 protein was drastically downregulated in the hippocampus of GluR6 and GluR5 KO mice. The exact mechanism remains unknown, and we ignore whether this is a compensative process or whether it results from the route that subunits follow to assemble into heteromeric receptors. However, this appears reminiscent of the situation observed for GABA receptors. In cerebellar granule cells from $\alpha 6$-deficient mice, a perturbation of other subunits takes place, and the $\delta$ subunit is degraded (Jones et al., 1997). This is a phenomenon beyond functional compensation, and it will be necessary to perform additional studies to determine the exact mechanism by which this takes place.

The somatodendritic receptors in mice (i.e., sIPSC frequency) were less sensitive to ATPA than to kainate, which is in contrast to what has been found in rats (Cossart et al., 1998; RodriguezMoreno et al., 2000). This might indicate that there are differences in receptor and/or isoform composition between species. Alternatively, the agonist sensitivity of orthologous subunits may differ among animal species, as has been found for recombinant GluR5 receptors of human and rat origin. In this case, human GluR5 receptors are much less sensitive to activation by domoate than those from rat (Alt et al., 2004).

Finally, we would like to emphasize the notion that KAR mosaics exist in hippocampal interneurons, each playing a different role. Although somatodendritic depolarization is mediated by GluR6-KA2 heteromers, modulation of GABA release involves receptors containing the GluR5 subunit (Clarke et al., 1997). This further emphasizes the existence of KARs at presynaptic GABAergic terminals controlling GABA release in a specific, direct, and regulated way. Interestingly, the segregation of KARs should allow us to design drugs to specifically target one function or another, producing drastically different effects. For instance, the specific activation of somatodendritic KARs at interneurons may result in a strong inhibition of principal cells (Khalilov et al., 2002). In contrast, antagonism of somatic receptors would reduce the inhibition of pyramidal neurons, whereas the antagonism of presynaptic receptors would potentiate it, probably producing an antiepileptic effect. Along these lines, recent results showed that LY382884 and other GluR5 antagonists behave as potent antiepileptic compounds in a model of hippocampal epilepsy (Smolders et al., 2002).

\section{References}

Alt A, Weiss B, Ogden AM, Knauss JL, Oler J, Ho K, Large TH, Bleakman D (2004) Pharmacological characterization of glutamatergic agonists and antagonists at recombinant human homomeric and heteromeric kainate receptors in vitro. Neuropharmacology 46:793-806.

Anderson WW, Collingridge GL (2001) The LTP program: a data acquisition program for on-line analysis of long-term potentiation and other synaptic events. J Neurosci Methods 108:71-83.
Ben-Ari Y (1985) Limbic seizure and brain damage produced by kainic acid: mechanisms and relevance to human temporal lobe epilepsy. Neuroscience 14:375-403.

Bortolotto ZA, Clarke VR, Delany CM, Parry MC, Smolders I, Vignes M, Ho KH, Miu P, Brinton BT, Fantaske R, Ogden A, Gates M, Ornstein PL, Lodge D, Bleakman D, Collingridge GL (1999) Kainate receptors are involved in synaptic plasticity. Nature 402:297-301.

Bureau I, Bischoff S, Heinemann SF, Mulle C (1999) Kainate receptormediated responses in the CA1 field of wild-type and GluR6-deficient mice. J Neurosci 19:653-663.

Christensen JK, Varming T, Ahring PK, Jorgensen TD, Nielsen EO (2004) In vitro characterization of NS3763, a non-competitive antagonist of GLUK5 receptors. J Pharmacol Exp Ther 309:1003-1010.

Clarke VR, Ballyk BA, Hoo KH, Mandelzys A, Pellizzari A, Bath CP, Thomas J, Sharpe EF, Davies CH, Ornstein PL, Schoepp DD, Kamboj RK, Collingridge GL, Lodge D, Bleakman D (1997) A hippocampal GluR5 kainate receptor regulating inhibitory synaptic transmission. Nature 389:599-603.

Cossart R, Esclapez M, Hirsch JC, Bernard C, Ben-Ari Y (1998) GluR5 kainate receptor activation in interneurons increases tonic inhibition of pyramidal cells. Nat Neurosci 1:470-478.

Cossart R, Tyzio R, Dinocourt C, Esclapez M, Hirsch JC, Ben-Ari Y, Bernard C (2001) Presynaptic kainate receptors that enhance the release of GABA on CA1 hippocampal interneurons. Neuron 29:497-508.

Cunha RA, Malva JO, Ribeiro JA (2000) Pertussis toxin prevents presynaptic inhibition by kainate receptors of rat hippocampal [(3)H]GABA release. FEBS Lett 469:159-162.

Frerking M, Malenka RC, Nicoll RA (1998) Synaptic activation of kainate receptors on hippocampal interneurons. Nat Neurosci 1:479-486.

Herb A, Burnashev N, Werner P, Sakmann B, Wisden W, Seeburg PH (1992) The KA-2 subunit of excitatory amino acid receptors shows widespread expression in brain and forms ion channels with distantly related subunits. Neuron 8:775-785.

Jiang L, Xu J, Nedergaard M, Kang J (2001) A kainate receptor increases the efficacy of GABAergic synapses. Neuron 30:503-513.

Jones A, Korpi ER, McKernan RM, Pelz R, Nusser Z, Makela R, Mellor JR, Pollard S, Bahn S, Stephenson FA, Randall AD, Sieghart W, Somogyi P, Smith AJ, Wisden W (1997) Ligand-gated ion channel subunit partnerships: $\mathrm{GABA}_{\mathrm{A}}$ receptor $\alpha 6$ subunit gene inactivation inhibits $\delta$ subunit expression. J Neurosci 17:1350-1362.

Khalilov I, Hirsch J, Cossart R, Ben-Ari Y (2002) Paradoxical anti-epileptic effects of a GluR5 agonist of kainate receptors. J Neurophysiol 88:523-527.

Lerma J (2003) Roles and rules of kainate receptors in synaptic transmission. Nat Rev Neurosci 4:481-495.

Lerma J, Paternain AV, Salvador N, Somohano F, Morales M, Casado M (1998) Excitatory amino acid-activated channels, In: Ion channel pharmacology (Soria B, Ceña V, eds), pp 399-421. Oxford: Oxford UP.

Lerma J, Paternain AV, Rodriguez-Moreno A, Lopez-Garcia JC (2001) Molecular physiology of kainate receptors. Physiol Rev 81:971-998.

Mulle C, Sailer A, Perez-Otano I, Dickinson-Anson H, Castillo PE, Bureau I, Maron C, Gage FH, Mann JR, Bettler B, Heinemann SF (1998) Altered synaptic physiology and reduced susceptibility to kainate-induced seizures in GluR6-deficient mice. Nature 392:601-605.

Mulle C, Sailer A, Swanson GT, Brana C, O'Gorman S, Bettler B, Heinemann SF (2000) Subunit composition of kainate receptors in hippocampal interneurons. Neuron 28:475-484.

Paternain AV, Morales M, Lerma J (1995) Selective antagonism of AMPA receptors unmasks kainate receptor-mediated responses in hippocampal neurons. Neuron 14:185-189.

Paternain AV, Herrera MT, Nieto MA, Lerma J (2000) GluR5 and GluR6 kainate receptor subunits coexist in hippocampal neurons and coassemble to form functional receptors. J Neurosci 20:196-205.

Paternain AV, Cohen A, Stern-Bach Y, Lerma J (2003) A role for extracellular $\mathrm{Na}^{+}$in the channel gating of native and recombinant kainate receptors. J Neurosci 23:8641-8648.

Rodriguez-Moreno A, Lerma J (1998) Kainate receptor modulation of GABA release involves a metabotropic function. Neuron 20:1211-1218.

Rodriguez-Moreno A, Herreras O, Lerma J (1997) Kainate receptors presynaptically downregulate GABAergic inhibition in the rat hippocampus. Neuron 19:893-901. 
Rodriguez-Moreno A, Lopez-Garcia JC, Lerma J (2000) Two populations of kainate receptors with separate signaling mechanisms in hippocampal interneurons. Proc Natl Acad Sci USA 97:1293-1298.

Selak S, Chan EK, Schoenroth L, Senecal JL, Fritzler MJ (1999) Early endosome antigen. 1: an autoantigen associated with neurological diseases. J Investig Med 47:311-318.

Smolders I, Bortolotto ZA, Clarke VR, Warre R, Khan GM, O’Neill MJ, Ornstein PL, Bleakman D, Ogden A, Weiss B, Stables JP, Ho KH, Ebinger G, Collingridge GL, Lodge D, Michotte Y (2002) Antagonists of GLU(K5)containing kainate receptors prevent pilocarpine-induced limbic seizures. Nat Neurosci 5:796-804.

Swanson GT, Feldmeyer D, Kaneda M, Cull-Candy SG (1996) Effect of
RNA editing and subunit co-assembly single-channel properties of recombinant kainate receptors. J Physiol (Lond) 492:129-142.

Varming T, Ahring PK, Sager TN, Mathiesen C, Johansen TH, Wätjen F, Drejer J (2001) Optimization of isatine oximes as neuroprotective AMPA receptor antagonists: in vitro and in vivo evaluation of SPD 502. In: Excitatory amino acids: ten years later (Turski L, Schoepp DD, Cavalheiro EA, eds), pp 193-205. Amsterdam: IOS.

Wilding TJ, Huettner JE (1995) Differential antagonism of alpha-amino-3hydroxy-5-methyl-4-isoxazolepropionic acid-preferring and kainatepreferring receptors by 2,3-benzodiazepines. Mol Pharmacol 47:582-587.

Wisden W, Seeburg PH (1993) A complex mosaic of high-affinity kainate receptors in rat brain. J Neurosci 13:3582-3598. 